\title{
Energy valuing of forest biomass residues in Bizkaia
}

\author{
E. Mateos ${ }^{1}$, J. M. González ${ }^{2}$ and J. M. Eguzkitza ${ }^{3}$ \\ ${ }^{1}$ Department of Chemical and Environmental Engineering ${ }^{2}$ Department of English and German Philology \\ ${ }^{3}$ Department of Applied Mathematics \\ E.U.I.T.I., University of the Basque Country, Plaza La Casilla 3, 48012 Bilbao (Spain) \\ ${ }^{1}$ Phone/Fax number: +0034 946014343 / +0034 946014300, e-mail: esperanza.mateos@ehu.es \\ ${ }^{2}$ Phone: +0034 946014322, e-mail. josemiguel.gonzalez@ehu.es ${ }^{3}$ Phone: +0034 946014411: josemari.eguzkitza@ehu.es
}

\begin{abstract}
.
The aim of this research work is the development of a methodology to quantify and yield cartography of the prospective energy production of residual biomass from the most representative forest species of Bizkaia, using a Geographic Information System (GIS) computer tool. A model of indirect estimation has been used in order to estimate the evolution of forest masses throughout in any area of Bizkaia. Arboreal species have timber-yielding utility, and this is the reason why the remains obtained after the forest treatments carried out for the preservation and improvement of arboreal masses, are those quantified in this work as energy production biomass (EPB). After analyzing statistically the results obtained, 52,214 metric tons of residual forest biomass per year are estimated. This means a potential energy supply of 32,011 toe per year. The estimation of biomass quantities that may generate forest activity will allow us to accomplish its planned exploitation, taking into account both economic and environmental aspects, with the aim of determining which the optimum location for setting up an energy production plant is.
\end{abstract}

\section{Key words}

GIS, biomass, forest residues, resources map

\section{Introduction}

Modern times have helped us to become aware of the serious environmental and energy problems due to the excessive use of energy in the so-called industrialized countries. The classical energy model based on the massive use of fossil fuels has become unsustainable both from an environmental point of view and from the viewpoint of exhaustion of this resource; accordingly, it is necessary to establish a new energy model based on the diversification of sources, rationalization, and efficiency in its consumption, as well as respect for the environment [1]. The goal pursued by the European Directive in 2008 is that $20 \%$ of the total energy consumed in Europe must come from renewable energy resources, among which biomass is included. Biomass of vegetal origin constitutes the $4^{\text {th }}$ worldwide exploited resource, this entailing $14 \%$ of energy consumption in the planet. However, the use of biomass for energy purposes is not very widespread in Europe and it just represents a mere 2\%, excluding Austria, Finland and Sweden, where it occupies a position of certain relevance. Conversely, biomass occupies a privileged position in developing countries, with an important increase from 1990 (736,000 toe) to 2003 (nearly 900,000 toe). In local terms, the goal for the Autonomous Community of the Basque Country (ACBC) in 2010 is to reach 795,000 toe of biomass exploitation. As far as the contribution of forests and lands from the ACBC as carbon drains is concerned, the net drain effect has been estimated in $1.33 \mathrm{MtCO} 2$ [2, 3].

Forest residues are those materials removed in timberyielding exploitation which are not usually extracted due to the fact that they cannot be converted into by-products, but they can be used as organic fuel. These residues come from the remains left in the forest after forestry, pruning, clearing, and final cutting remains in forest production (cleaning, pruning, tree felling). They can be utilized for energy uses due to their excellent features as fuels. One of the main barriers for using this resource is the lack of knowledge of its real forest-mass biomass production capacity. This is a key aspect, since it prevents to know the steady biomass supply that could assure production in thermoelectric plants that might use it $[4,5]$. The main aim of this project can be described within the following master lines:

- Selection of the main forest species in the zone.

- Obtaining residue estimators by means of the use of biomass production equations, so that they let us calculate the residual biomass per arboreal species obtained from forest treatment. 
- Integration of the forestry estimation biomass model in a Geographic Information System (GIS), so that data can be processed.

- Determination of the Residual Forestry Biomass (RFB) energy potential.

- Integration of RFB energy potential methodology in the GIS.

- Cartography of results for obtaining the global map of RFB energy resources in Bizkaia.

\section{Description of the area of study}

Bizkaia is located in the north of Spain at latitude $43^{\circ} 16^{\prime} \mathrm{N}$ and longitude $2^{\circ} 56^{\prime} \mathrm{W}$. It extends over $2,217 \mathrm{~km}^{2}$, and it is an abrupt and mountainous province, crossed by deep valleys that descend quickly towards the sea from the near mountains close to the also abrupt and cliffy coast. From a geological point of view, due to the materials that appear in the area, most of the surface in this district is made up of Mesozoic terrain with predominance of the Lower Cretaceous (Aptian). The lands of Bizkaia form a very rugged set in which erosion has produced an important dissection of the land (Figure 1)

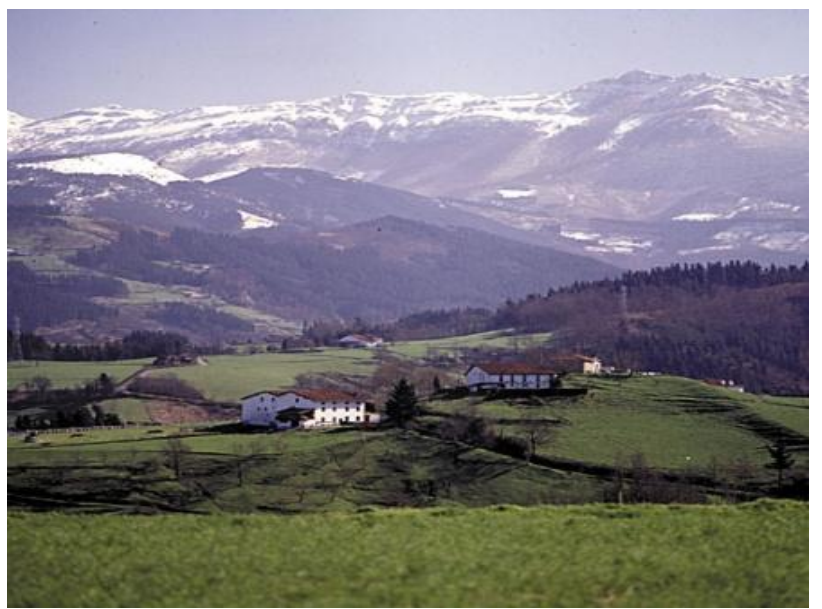

Fig. 1. Bizkaia's landscape

The climate in the area, warm and humid (Atlantic climate), is conditioned by its proximity to sea, and it notably influences the proliferation of forest species, typical in this climate, especially pine forests. Data taken from the Tercer Inventario Forestal Nacional (IFN-3) depict that forest surface in this province is continuously increasing and it already amounts to more than 130,000 ha, this representing $59.1 \%$ of the total surface. For carrying out this project, it has been decided to select those species that fulfill a double criterion: high presence in the area of study, according to data obtained from the IFN-3, and high potential for exploitable residue generation from the viewpoint of energy. The most widespread vegetable species are Pinus radiata (50\%) (Figure 2), followed by Quercus robur (10\%), and Eucalyptus globules (8\%) (Figure 3). Scrub surfaces have not been considered in this study, since the surface they occupy in the territory is rather average $(8.6 \%)$, it presents low productivity, and it is a very scattered resource.

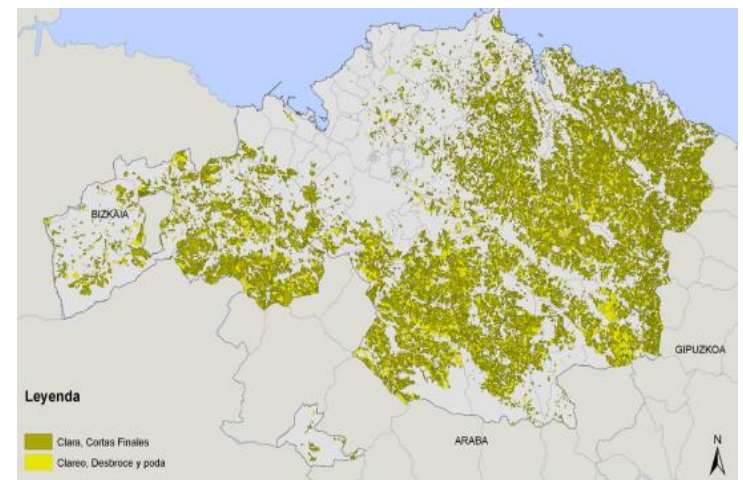

Fig. 2. Pinus radiata plot map in Bizkaia

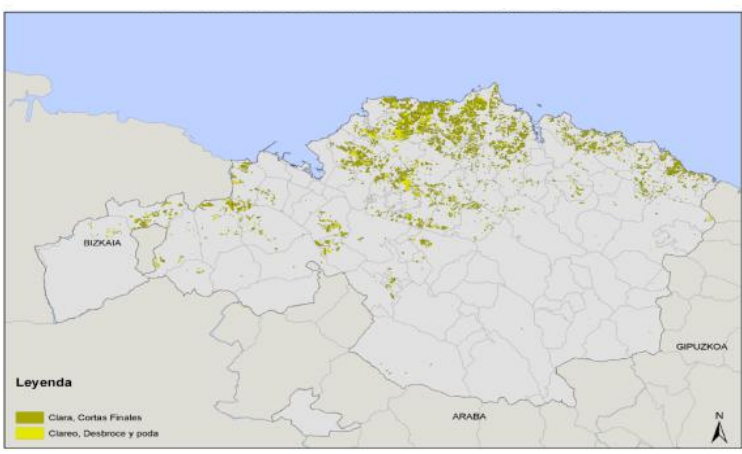

Fig. 3. Eucalyptus globules plot map in Bizkaia

In this project, it has been rejected to consider the species Quercus robur as a source of potential residue biomass, despite its widespread distribution, based on the high value added reached by by-products coming from forest operations.

\section{Methodology}

After reviewing different estimating methods for forest biomass residue, an indirect methodology based on the use of linealized alometric equations as logarithmic model has been selected [7-12]. The aim of these equations is to link the total dry biomass of the tree, or some of its components, with the average diameter:

$$
\operatorname{Ln} b=a+b \operatorname{Ln} d
$$

Where Y represents the biomass for each fraction (expressed in $\mathrm{kg}$ dry mass), $\mathrm{d}$ the average diameter in $\mathrm{cm}$ and ' $a$ ' and ' $b$ ' are the two specific regression parameters. This model allows straightforward calculations and improves the goodness of the statistical analysis. However, the final result should be multiplied by a correction factor -obtained from the standard deviation of the estimate- in order to eliminate the bias introduced by the logarithmic transformation. Parameters ' $a$ ' and ' $b$ ' as well as the bias correction factor take different values depending on the species under consideration [13]. These equations are applied to the bigger feet $(\mathrm{BF})(\mathrm{R}>7.5 \mathrm{~cm})$. In the smaller feet $(\mathrm{SF})(\mathrm{R}$ $<7.5 \mathrm{~cm})$, most of the tree is not good for wood exploitation, this making the tree become almost $100 \%$ biomass residue. However, in this research work a more 
conservative criterion has been used, and only $80 \%$ of the total weight has been considered residue.

An appropriate method for estimating biomass stocks is the use of the concept "stratum", which is defined in the IFN3 [6]. Every stratum is formed by grouping the forest surfaces (tesseras) of similar features, whose perimeter is marked out to a 1:50,000 scale. The IFN3 defines 12 scales in Bizkaia (Table I).

Table I. - IFN3 strata for the territory of Bizkaia.

\begin{tabular}{|c|c|c|c|c|}
\hline Stratum & Dominant forest grouping & Mass state & $\begin{array}{c}\text { Fqc } \\
(\%)\end{array}$ & $\begin{array}{c}\text { Room } \\
(\mathrm{Ha})\end{array}$ \\
\hline 1 & Pinus radiata & Fustal. Latizal & $>=70$ & 45,210 \\
\hline 2 & Pinus radiata & Fustal. Latizal & $5-69$ & 5,589 \\
\hline 2 & Pinus radiata & $\begin{array}{c}\text { Brave } \\
\text { mountain. } \\
\text { Restocked. }\end{array}$ & $\begin{array}{c}40- \\
100\end{array}$ & 12,382 \\
\hline 4 & $\begin{array}{c}\text { P. radiata and P. nigra with Q robur, } \\
\text { C. sativa and Brook trees }\end{array}$ & $\begin{array}{c}\text { Brave } \\
\text { mountain. } \\
\text { Restocked. }\end{array}$ & $5-39$ & 8,655 \\
\hline 5 & $\begin{array}{c}\text { Lawsonian Chamaecyparis } \\
\text { Pseudotsuga menziesii and } \\
\text { Larix spp. }\end{array}$ & All & $5-100$ & 4,297 \\
\hline 6 & Pinus pinaster and Pinus nigra & Fustal. Latizal & $5-100$ & 5,250 \\
\hline 7 & $\begin{array}{c}\text { Q. robur and Q. robur with Casativa, } \\
\text { C. nut, A. unedo or with } \\
\text { P. radiata }\end{array}$ & All & $5-100$ & 17,650 \\
\hline 8 & $\begin{array}{c}\text { Q. ilex and Q. ilex with Quercus } \\
\text { faginea, Arbutus unedo or with } \\
\text { Quercus robar }\end{array}$ & All & $5-100$ & 6,563 \\
\hline 9 & Eucalyptus spp. & Fustal. Latizal & $5-100$ & 9,183 \\
\hline 10 & $\begin{array}{l}\text { Eucalyptus spp. and Eucalyptus } \\
\text { spp.with Pinus radiata }\end{array}$ & $\begin{array}{c}\text { Brave } \\
\text { mountain. } \\
\text { Restocked. }\end{array}$ & $5-100$ & 3,804 \\
\hline 12 & $\begin{array}{l}\text { F. sylvatica and F. sylvatic with Betul } \\
\text { spp., Castanea sativa or with Q.robur }\end{array}$ & All & $5-100$ & 5,523 \\
\hline Brook trees & All & $5-100$ & 2,522 \\
\hline
\end{tabular}

Strata 1, 2 and 3, in which Pinus radiata is the dominant species, are selected. As far as Eucalyptus is concerned, stratum 9 is selected since its mass state (fustal, latizal) advises a final clearing or cut. The state of Eucalyptus mass in stratum 10 (restocked brave mountain), does not currently add any residue biomass in a significant way.

The most adequate forest treatments that can be carried out in a ten-year-old horizontal stratum are identified, thus the amounts of residual forest biomass that might be obtained in each stratum considering such treatments are estimated. Once the forest masses have been classified per strata, the most adequate forest treatments that can be carried out in each stratum are identified. The forest biomass residue quantities that could be obtained in each stratum are estimated from those treatments (Figure 4).

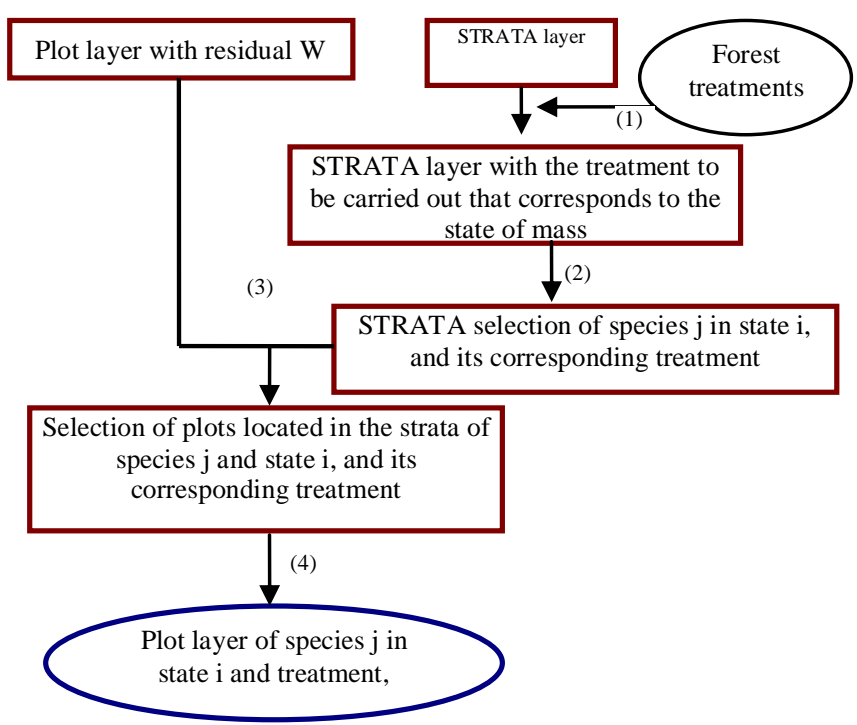

Fig. 4. Flow chart to obtain the layer with the plots of each forest species.

In this way, in order to determine the residue estimator generated in each sampling plot, it is only necessary to know what the stratum under which the catalogued surface from which the plot was taken is. For estimating the amount of annual biomass (metric tons/year) that might be generated by current forest masses in Bizkaia, the methodology applied uses a Geographic Information System (GIS) with the help of the Arcview GIS 9 program. In this way, it has been possible to process an important amount of data and to manage the results obtained [14-16].

First of all, the quantity of forest residue generated by the main forest species of Bizkaia within the strata in which those species are predominant is estimated. Then, the energy potential that could be obtained with those residues, considering their sustainable exploitation, is estimated.

The potential energy of residue $(\mathrm{P})$ is a function of the ICP (Inferior Calorific Power) times the total residue for each species considered:

$$
\mathrm{P}=\mathrm{S} \times \mathrm{E}_{\mathrm{r}} \mathrm{x} \mathrm{ICP}
$$

Where $\mathrm{P}$ represents potential energy (toe per year), $\mathrm{S}$ represents the surface (ha) susceptible of generating forest residue, $\mathrm{Er}$ the residue estimator (measured in metric tons/ha-year), and ICP the inferior calorific power $(\mathrm{MJ} / \mathrm{kg})$ of forest residue obtained at the same humidity level as the one at which productivity is considered. The humidity level considered in this work has been $30 \%$, this being the humidity of residue biomass once it has remained on the soil a few days.

The biomass potential energy expressed in $\mathrm{KJ} / \mathrm{ha}$ is calculated by using a GIS computer tool (Arcview GIS9). For this to be accomplished, the vectorial information that corresponds to the distribution of forest species is rasterized with a pixel of 1 ha of spatial resolution. This means that each unit of information maintains a unique area. 
With the aim of characterizing RFB from the viewpoint of energy, elemental analyses $(\% \mathrm{C}, \mathrm{H}$ and $\mathrm{N})$, humidity, and Superior Calorific Potential of each sample have been estimated. All the determinations have been carried out in triplicate in the laboratories of the University of the Basque Country (Segiker). This fieldwork consisted of gathering samples of the most representative species in six different locations of the province of Bizkaia (Erandio, Abanto-Zierbena, Durango, Galdames, Muskiz and Karrantza). The samples were collected during the months of December 2009 and January 2010. In each of the sampling areas, the samples of forest biomass collected roughly $2 \mathrm{~kg}$ per sample- come from forest treatments of branches (with a variable diameter ranging between $3 \mathrm{~cm}$ and $1 \mathrm{~cm}$ ) and needles (pinus) or leaves (E. globules).

\section{Results}

Table II shows the mean values obtained after the energy characterization of RFB representative samples in Bizkaia.

Table II. - Elemental analysis and Calorific Potential

\begin{tabular}{|c|c|c|c|c|c|c|}
\hline $\begin{array}{c}\text { Forest } \\
\text { Species }\end{array}$ & $\begin{array}{c}\mathrm{C} \\
(\% \mathrm{~ms})\end{array}$ & $\begin{array}{c}\mathrm{H} \\
(\% \mathrm{~ms})\end{array}$ & $\begin{array}{c}\mathrm{N} \\
(\% \mathrm{~ms})\end{array}$ & $\begin{array}{c}\text { Humidity } \\
(\text { bhcut })\end{array}$ & SCP & ICP** \\
\hline$P$. radiata & 51.768 & 6.078 & 0.974 & 44 & 21.2 & 19.8 \\
\hline E. globulus & 51.046 & 6.422 & 1.197 & 52.5 & 21.1 & 19.7 \\
\hline
\end{tabular}

SCP*: Superior Calorific Power, ICP**: Inferior Calorific Power

The estimation of remains from RFB has been carried out in two different ways. On the one hand, stratum per stratum, and on the other hand, all of them together. In each situation the estimation is accomplished by means of a confidence interval at a $95 \%$ level for the mean residue in metric tons per year. Normality tests of the data were also carried out to determine if the values of the random variable Eri (estimator of residue in metric tons/ha and year) present a normal distribution. In order to do so, five different tests that belong to the $\mathrm{R}$ statistical software pack nortest were used (Anderson-Darling; KolmogorovSmirnov; Cramer-von Mises; Pearson and ShapiroFrancia) [17-18]. Figures 5 and 6 show the values of the residue estimator (metric tons/ha year) that correspond to stratum 1 (dominant species Pinus radiata) and stratum 9 (dominant species Eucalyptus globulus) from Bizkaia

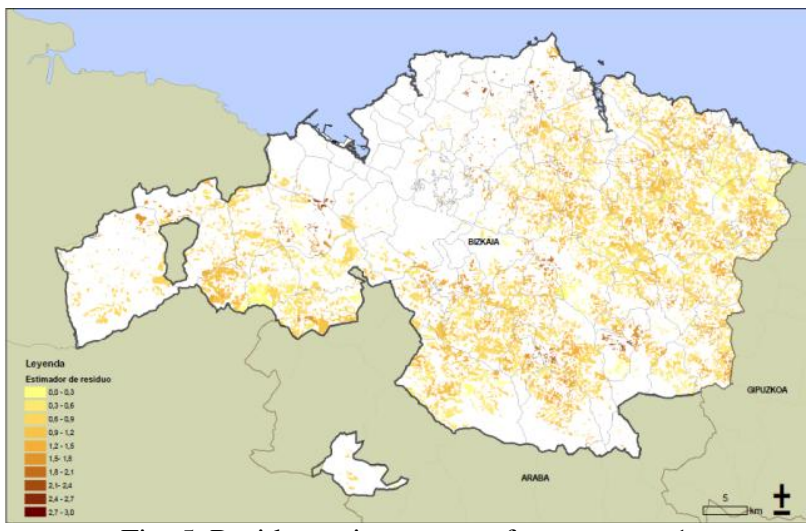

Fig. 5. Residue estimator map from stratum 1

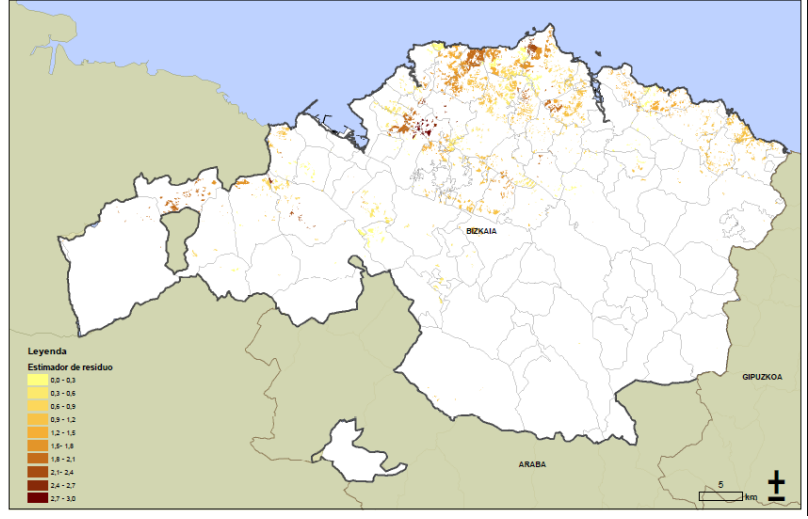

Fig. 6. Residue estimator map from stratum 9

The results obtained after the statistical analyses of the data showed that the amount of mean forest biomass achieved within an interval of $95 \%$ is 52,214 metric tons/year, with an estimated 32,011 toe/year energy potential.

\section{Acknowledgement}

We would like to acknowledge Vicerrectorado de Investigación de la Universidad del País Vasco-Euskal Herriko Unibertsitatea for financing project NUPV08/22 within which this research has been carried out.

The authors thank the technicians of SGIker's [UPV/EHU] Service, financed by the National Program for the Promotion of Human Resources within the National Plan of Scientific Research, Development and Innovation, Ministerio de Ciencia e Innovación, Fondo Social Europeo and Gobierno Vasco/Eusko Jaurlaritza, Dirección de Política Científica for the Elemental Analysis measurements.

\section{References}

[1] IPCC Climate Change 2007, Report of the Intergovernmental Panel on Climate Change, S,D. Solomon, et al. (eds.). Cambridge University Press, (2007), pp. 154-162.

[2] E. Tolosana, Manual técnico para el aprovechamiento y elaboración de biomasa forestal, Fucovasa y MundiPrensa, Madrid, (2009).

[3] Basoa Fundazioa, Guía de buenas prácticas en el sector forestal y de transformación de la madera, Gobierno Vasco, (2007).

[4] A. García, F. Pérez and J. de la Riva Fernández, Evaluación de los recursos de biomasa residual forestal mediante imágenes del satélite Landsat y SIG, GeoFocus, $n^{\circ}$ 6, (2006), pp. 205-230.

[5] J. Domínguez, P. Ciria, L.S. Esteban, D. Sánchez and P. Lasry, Evaluación de la biomasa potencial como recurso energético en la región de Navarra, Geofocus, Rev. Int. Ciencia y Tecnología de la Información Geográfica. $\mathrm{n}$ ³, (2003), pp. 1-10.

[6] Tercer Inventario Forestal Nacional en versión digital para la provincia de Vizcaya (IFN3) Ministerio de Medio Ambiente, (2006), http://www.mma.es/portal/secciones/

[7] G. Montero, R. Ruiz-Peinado, M. Muñoz, Producción de biomasa y fijación de $\mathrm{CO} 2$ en los montes españoles, Monografías INIA, (2005). 
[8] L.S. Esteban, et al., Evaluación de los recursos de biomasa forestal en la provincia de Soria. Análisis de alternativas para su aprovechamiento energético CIEMAT, (2004).

[9] M.T. Ter-Mikaelian and M.D. Korzukhin, Biomass equations for sixty-five North American tree species, Forest Ecology and Management (1997), pp. 1-24.

[10] L.S. Esteban, M. Ciria and J.E. Carrasco, An assessment of relevant methodological elements and criteria for surveying sustainable agricultural and forestry biomass by-products for energy purposes Bioresources, $\mathrm{n}^{\mathrm{o}} 3$, (2008), pp. 910928.

[11] L.S. Esteban et al., Biomass Resources and Costs in Spain and Southern EU Countries. Clean Hydrogen-rich Synthesis Gas Report, Chrisgras fuels from biomass, $\mathrm{n}^{\circ} 1$ Deliverable $\mathrm{n}^{\circ}$ 36, CIEMAT, (2009).

[12] A. Merino, C. Rey, J. Brañas and R. Rodríguez-Soalleiro, Biomasa arbórea y acumulación de nutrientes en plantaciones de Pinus radiata D. Don en Galicia, Invest. Agraria, Sist. Recur. For. 12 (2), (2003), pp.85-98.

[13] F. López-Rodríguez, C. Pérez Atanet, F. Cuadros Blázquez, A. Ruiz Celma Spatial assessment of the bioenergy potential of forest residues in the western province of Spain, Caceres Biomass and Bioenergy, Volume 33, Issue 10, October 2009, Pages 1358-1366

[14] O. Masera, A. Ghilardi, R. Drigo, A. Trossero, and M. WISDOM, A GIS-based supply demand mapping tool for woodfuel management, Biomass and Bioenergy, 30 (7), (2006), pp. 618-637.

[15] E. Mateos and J. González, Forest Residual Biomass estimation based on GIS, 09SRD international Congress on Energy and Environment Engineering and Management Portalegre, Portugal, (2009).

[16] Ciemat, Desarrollo de una Aplicación en base de Sistema de Información Geográfica (SIG) para la Evaluación de Recursos de Biomasa a través de Internet. Especificaciones técnicas, Centro de Desarrollo de Energías Renovables, Soria, (2009).

[17] S. Wolfram, The Mathematica Book, Champaign (Illinois), Wolfram Media, Inc., (2003).

[18] P. Spector, Data Manipulation with R, New York, Springer, (2008). 